\title{
Naevus Sebaceous of Jadassohn
}

*Santosh Kumar ${ }^{1}$, Jasninder Singh ${ }^{1}$

Sri Lanka Journal of Child Health, 2018; 47(2): 179-180

DOI: http://dx.doi.org/10.4038/sljch.v47i2.8490

(Key words: Naevus Sebaceous of Jadassohn)

\section{Case report}

A boy weighing $2500 \mathrm{~g}$ was delivered at 37 weeks of gestation by a mother with no significant antenatal history. He presented at birth with yellowish-white to pink papillomatous plaques over left side of the scalp, eyelid, cheeks, philtrum and chin (Figure 1).

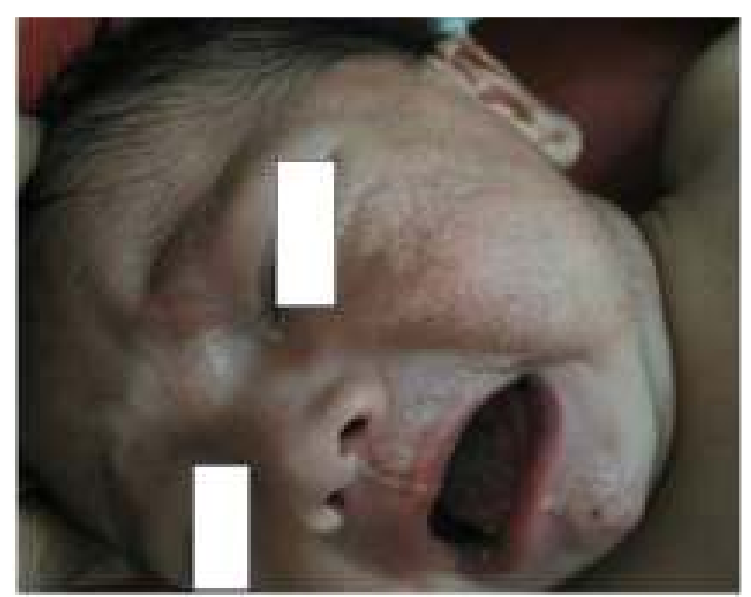

Figure 1: Naevas sebaceous

*Permission given by parents to publish photograph

Histopathological examination of the skin biopsy specimen showed papillomatous epidermal hyperplasia and numerous sebaceous glands with no hair follicles. This was suggestive of naevus sebaceous (NS) (Figure 2). Physical and neurological examinations were normal. X-ray of the skull was normal.

\footnotetext{
$\overline{{ }^{1} \text { Mata Gujari Memorial Medical College and Lions }}$ Seva Kendra Hospital, Kishanganj, Bihar, India

*Correspondence: santoshaiims08@gmail.com
}

(Received on 3 November 2016: Accepted after revision on 23 December 2016)

The authors declare that there are no conflicts of interest

Personal funding was used for the project.

Open Access Article published under the Creative

Commons Attribution CC-BY

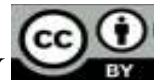

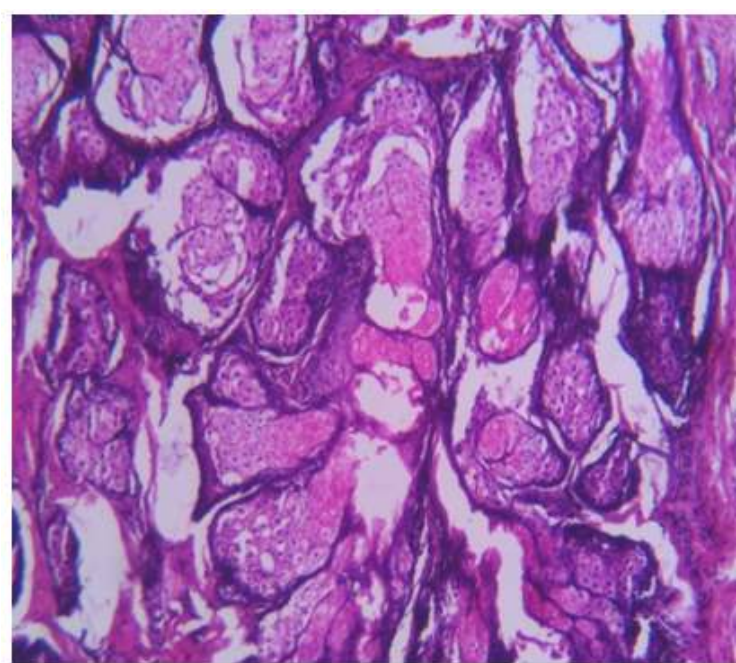

Figure 2: Histopathology showing papillomatous epidermal growth, sebaceous gland hyperplasia and no hair follicles

\section{Discussion}

Naevus sebaceous (NS) of Jadassohn is a congenital abnormality first described by the dermatologist Josef Jadassohn in $1895^{1}$. It is a hamartoma of the epidermis, hair follicles, sebaceous and apocrine glands ${ }^{1}$. It is probably due to mosaic genetic mutations in HRAS and KRAS genes ${ }^{2}$. It is often present at birth as a solitary lesion usually located over the head and neck region. The lesions are usually yellowish-white to pink papillomatous plaques velvety in consistency. NS becomes verrucous and nodular at puberty indicating androgen sensitivity ${ }^{3}$. Diagnosis of NS is usually based on the characteristic appearance of lesions. Skin biopsy is done to rule out similar conditions like epidermal naevus syndrome, giant seborrhoeic keratosis, sebaceous adenoma, sebaceous carcinoma and sebaceoma ${ }^{3}$. NS is usually benign but monitoring for changes to lesions is imperative as progression to basal cell carcinoma has been reported ${ }^{3}$. Treatment, if needed, is by surgical excision, though carbon dioxide laser and photodynamic therapy have also been tried ${ }^{4}$. 


\section{References}

1. Segars K, Gopman JM, Elston JB, Harrington MA. Naevus sebaceous of Jadassohn. Eplasty 2015; 15: ic38.

Available

from: https://www.ncbi.nlm.nih.gov/pmc/articles/P MC4518814/

PMid: 26229574 PMCid: PMC4518814

2. Lee JD, Kim HS. Cerebriform naevus sebaceous. New England Journal of Medicine 2015; 373(3):262.

https://doi.org/10.1056/NEJMicm1412178 PMid: 26176383
3. Jensen AL, Florell SR, Vanderhooft SL, Bale AE. Basal cell carcinoma arising in a naevus sebaceous in a child with facial trichoepitheliomas. Pediatric Dermatology 2011; 28(2):138-41. https://doi.org/10.1111/j.15251470.2010.012 27.x

PMid: 20738793

4. Avhad G, Ghuge P, Jerajani H. Cerebriform naevus sebaceous of Jadassohn. Indian Pediatrics 2013; 50(11): 1072. PMid: 24382915 